\title{
Mineralogy and Geochemistry of Qulqula Limestone in Shenrui, Halabja Governorate, Northeastern Iraq
}

\author{
Nian Wali Samin \\ College of Basic Education \\ University of Halabja
}

(Received 24/6/2021 , Accepted 10/11/2021)

\begin{abstract}
This study focuses on the mineralogy and geochemistry of the limestone unit of the Qulqula Formation (Early Cretaceous). The age and stratigraphic position of this formation are controversial because of insufficient studies and the complex structure of the occurrence area. Twenty samples were selected and analyzed which represent six sections: Sarkan, Awera, Griana1, Griana2, Hawar, and Hawara Kon at the Mount of Shenrui in Halabja area located in Kurdistan Region, northeastern Iraq near the IraqiIranian borders. The mineralogical study by the X-ray diffraction technique shows that the samples are composed of $70.14 \%$ calcite, and $28.07 \%$ quartz. The geochemical analysis shows that $\mathrm{CaO}$ is abundant in most of the studied samples, the increases of $\left(\mathrm{SiO}_{2}, \mathrm{Al}_{2} \mathrm{O}_{3}, \mathrm{Fe}_{2} \mathrm{O}_{3}, \mathrm{TiO}_{2}\right.$, and $\left.\mathrm{K}_{2} \mathrm{O}\right)$, and the decrease in $(\mathrm{CaO}$ and $\mathrm{MgO})$ leads to the change of limestone to siliceous type. The limited dolomitization can be confirmed by the low concentration. The component $\mathrm{Sr}$ has a negative correlation for both major and trace elements. On the other hand, $(\mathrm{Cr}, \mathrm{Co}, \mathrm{Ni}, \mathrm{V}$, and $\mathrm{Zr})$ have a positive correlation with $\left(\mathrm{MgO}, \mathrm{Fe}_{2} \mathrm{O}_{3}, \mathrm{SiO}_{2}, \mathrm{Al}_{2} \mathrm{O}_{3}, \mathrm{~K}_{2} \mathrm{O}\right.$, and $\left.\mathrm{TiO}_{2}\right)$, this may indicate the effect of the basic rocks in surrounding areas enriching limestone with these elements.
\end{abstract}

Keywords: Mineralogy, Geochemistry, limestone, Qulqula, North Iraq.

معدنية وجيوكيميائية الحجر الجيري لقلقة في شنروي حلبجة، شمال شرقي العراق

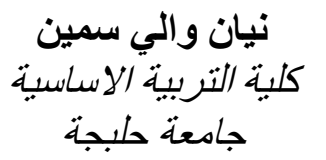

\section{الملخص}

تركز هذه الدر اسة على معدنية وجيوكيميائية الحجر الجيري في تكوين قلقلة. يعتبر العمر والموقع الطباقي

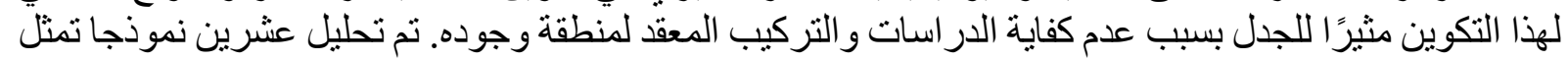

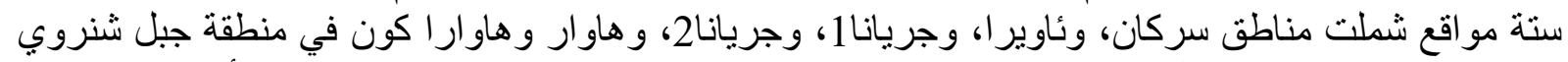

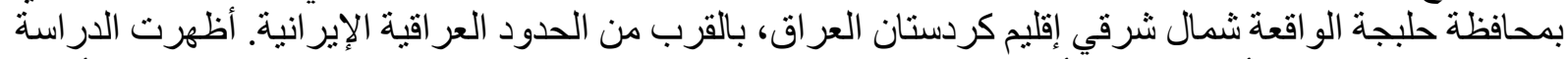

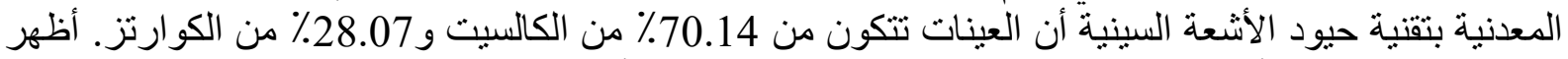

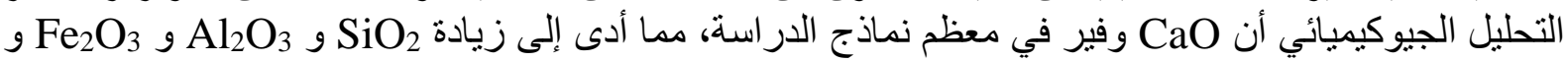

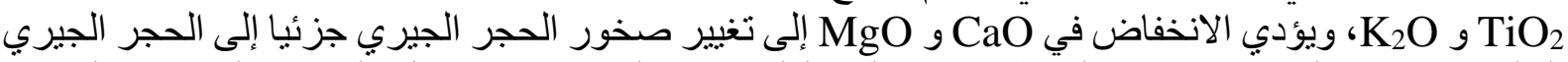

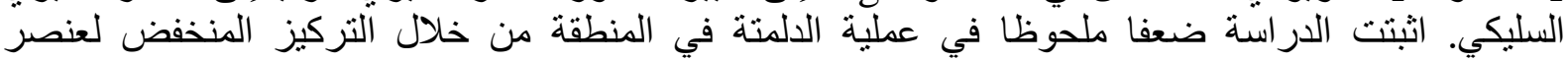
السنترونتيوم Sr و العلاقة العكسية بين تراكيز العناصر النزرة وتر اكيز العناصر الرئيسة الموجودة في منطقة

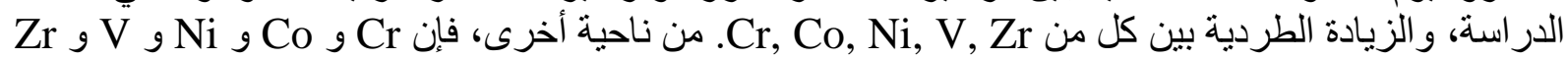




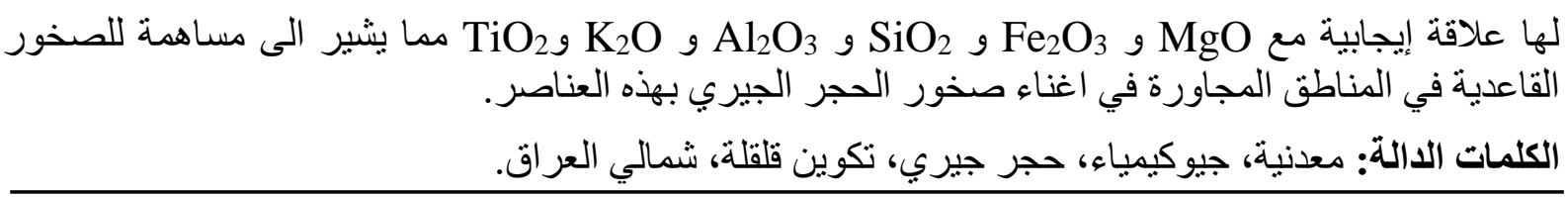

\section{INTRODUCTION}

Qulqula Formation was first mentioned by Bolton (1955). The formation is a part of the Qulqula group, which consists of Qulqula radiolarian and Qulqula conglomerate Formations. Qulqula group forms of thick successions of bedded chert, shale, and siliceous limestone (Buday, 1980; Jassim and Goff, 2006). The studied area is characterized by obscured anticlines and synclines, which have been stacked together as very thick and tight packages of layers and overturned towards the southwest or even overthrusts (Raza, 2009).

The studied area is defined as the Crushed Zone, because of its high deformation. The contact of the formations is difficult to be determined and marked because of the intensive folding, faulting, and thrusting (Stocklin, 1968). Qulqula radiolarian series was divided by Jassim et al. (1984) into two formations namely Qulqula Formation (AptianAlbian) and Qulqula conglomerate Formation (Cenomanian), Qulqula conglomerates are composed of thickly conglomerate limestone and cherty grit, interbedded with grey marly shales, chert, and detrital Limestone. Qulqula conglomerate was found at the base of the Qulqula Formation. The conglomerate crops out between Chuarta and Said Sadiq (Karim, 2003). Moreover, Sissakian (2005) mentioned that the contact between Qulqula Formation and Qulqula conglomerate Formation is gradational. In the meantime, Raza, (2009) referred that the lower member of the Qulqula Formation consists of an alternation of more than four detrital limestone successions, each one is more than $25 \mathrm{~m}$ thick. The current study aims to identify the mineralogical composition of limestone facies of the Qulqula Formation, as well as to study the geochemistry of major and trace elements and their distribution in limestone to detect the origin and the depositional environment of the formation.

\section{GEOLOGICAL SETTING}

The study area is located within the western part of the Zagros Fold-Thrust Belt, which is developed from the basin fill of the Neo-Tethys and deformations that accompanied colliding of the Iranian and Arabian plates (Law et al, 2013). Dunnington, (1958) believed that the thrust zone has developed during the Alpine Orogeny which started from Upper Cretaceous time and continued through the Tertiary, where it is accentuated during the Pliocene time. Stocklin (1968) called the studied area "crushed zone" because it is highly deformed on a large and small scale. According to Karim (2003), the deformation and development of the studied area mainly began from Campanian. (Baziany, 2006) mentioned that the continental part of the Iranian and Arabian plates was collided with Iranian and a foreland basin is formed. Karim (1975) inferred the age of Albian to Cenomanian depending on the study of foraminifera. Structurally, the study area is located within the Imbricated and Thrust Zones (Buday and Jassim, 1987, Jassim and Goff, 2006) which consists of a very long belt in the Thrust Zone. 


\section{LOCATION OF THE STUDY AREA}

The studied area is located in northeastern Iraq, in the southeastern part of Halabja governorate in the Iraqi Kurdistan Region, where it extends between $\left(35^{\circ} .07^{\prime} .47^{\prime \prime} \mathrm{N}\right.$ $\left.35^{\circ} .11^{\prime} .32^{\prime \prime} \mathrm{N}\right)$ and $\left(46^{\circ} .03^{\prime} .96^{\prime \prime}-46^{\circ} .08^{\prime} .57^{\prime \prime} \mathrm{E}\right.$ (Fig. 1). Six locations are selected for the detailed study of the lower part of the Qulqula limestone Formation (Table-1). The sampling is located at the Mount of Shenrui. The Mount of Shenrui takes a rectangular shape in a southeastern-northwestern direction with a length of $20.2 \mathrm{~km}$, and the average width of the study area from east to west about $10 \mathrm{~km}$ covers an area of about 126.03 $\mathrm{Km}^{2}$ where its northern edges are adjacent to the Sharzur plain. As for its southern margins, they extend with the Sirwan River for a length of $11.8 \mathrm{~km}$, as it forms a part of the Iraq and Iran border.

Table 1: Location of the Studied Sections

\begin{tabular}{|l|c|c|c|}
\hline Section & No. of Samples & Location & Thickness(m) \\
\hline Sarkan & 3 & $46^{\circ} .03^{\prime} .96^{\prime \prime} \mathrm{E} 35^{\circ} .11^{\prime} .32^{\prime \prime} \mathrm{N}$ & 3 \\
\hline Awera & 4 & $46^{\circ} .06^{\prime} .06 " \mathrm{E} 35^{\circ} .10^{\prime} .12^{\prime \prime} \mathrm{N}$ & 8 \\
\hline Griana1 & 4 & $46^{\circ} .08^{\prime} .57^{\prime \prime} \mathrm{E} 35^{\circ} .07^{\prime} .47^{\prime \prime} \mathrm{N}$ & 30 \\
\hline Griana2 & 3 & $46^{\circ} .07^{\prime} .91^{\prime \prime} \mathrm{E} 35^{\circ} .07^{\prime} .95^{\prime \prime} \mathrm{N}$ & 10 \\
\hline Hawar & 3 & $46^{\circ} .07^{\prime} .29^{\prime \prime} \mathrm{E} 35^{\circ} .09^{\prime} .23^{\prime \prime} \mathrm{N}$ & 3.5 \\
\hline HawaraKon & 3 & $46^{\circ} .06^{\prime} .66^{\prime \prime} \mathrm{E} 35^{\circ} .08^{\prime} .48^{\prime \prime} \mathrm{N}$ & 5 \\
\hline
\end{tabular}

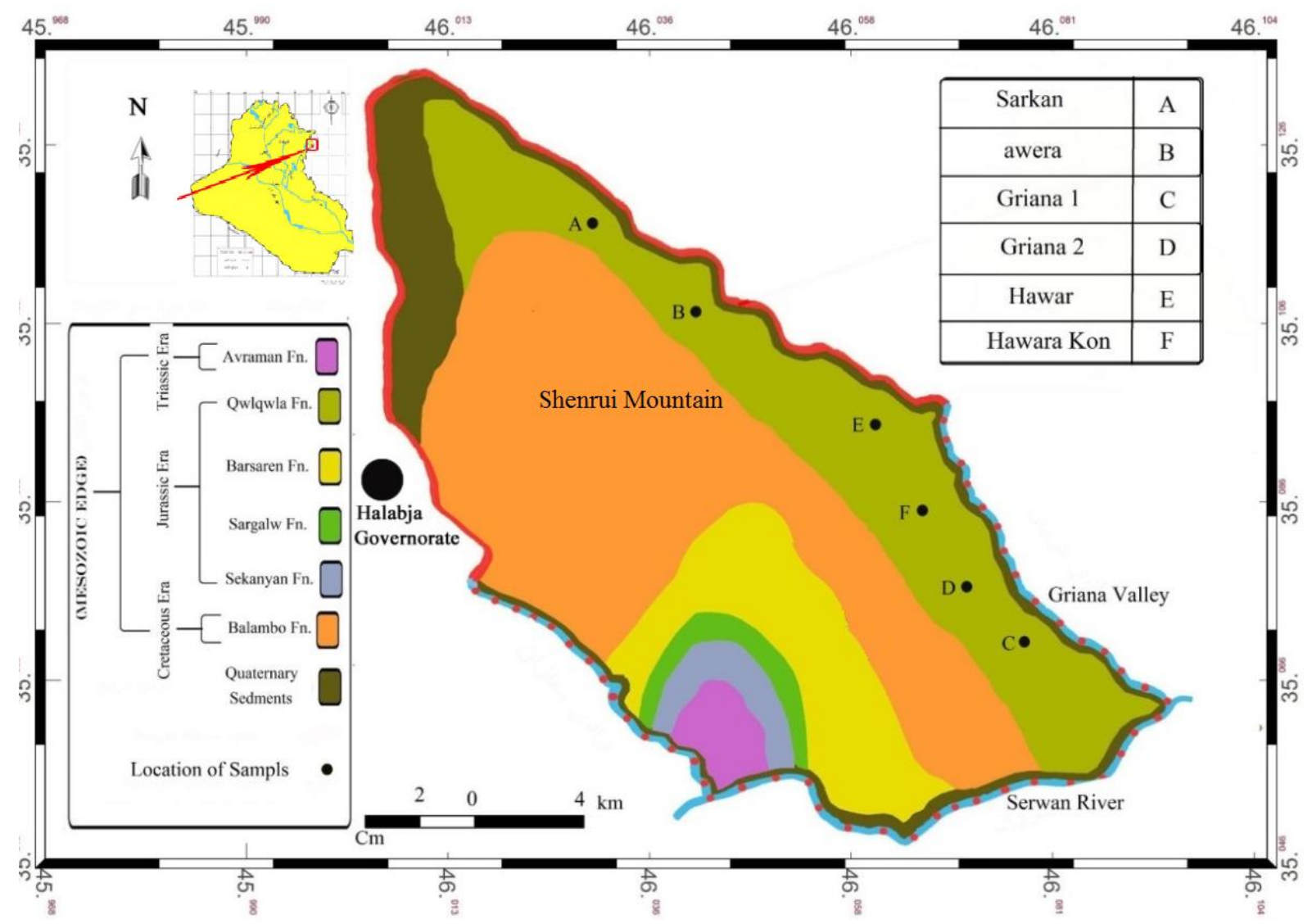

Fig.1: The Geological map of the study area and location of the samples. (Iraq Geological Survey, 2000) 


\section{LITHOLOGY OF THE QULQULA FORMATION}

The formation consists of different members. The lower member consists predominantly of moderately thickly bedded, oolitic, and detrital limestone with thick beds of white chert. Both limestone and chert layers are inter-bedded with grey marly shale. The middle member is composed of thinly bedded, red and grey, and green shale with intercalation of cherty radiolarian limestone and dark ferruginous shale. Moreover, the upper part is dominated by a thick sequence of dark red ferruginous-siliceous shale and ruby mudstone with occasional beds of oolitic and detrital limestone (Raza, 2009). A conglomeratic bed exists at the base of the Qulqula Formation having a thickness of $0.2-2 \mathrm{~m}$ and forming the lower boundary of the formation in the middle part of the studied area. The Formation in the studied area consists of more than four limestone successions; all are situated above the conglomerate bed. A dense interval of alternations of bedded chert and marl separate these successions (Figs.2and3).

\begin{tabular}{|c|c|c|c|}
\hline $\begin{array}{l}\text { Thick } \\
\text {-ness } \\
\text { (cm) }\end{array}$ & $\begin{array}{c}\text { Sampl } \\
\text { No. }\end{array}$ & $\begin{array}{l}\text { Lithologic } \\
\text { column }\end{array}$ & Lithological description \\
\hline 50 & $\begin{array}{l}1 \\
2\end{array}$ & 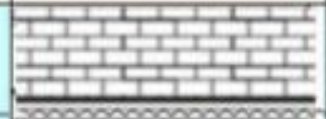 & $\begin{array}{l}\text { White to gray limestone and gray to } \\
\text { black limestone. }\end{array}$ \\
\hline 30 & 3 & 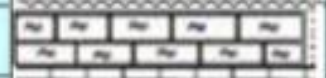 & White to gray marly limestone. \\
\hline 20 & 4 & 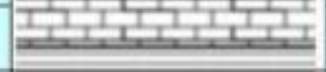 & black limestone (bituminous). \\
\hline 50 & 5 & (20 & High fissile marly limestone. \\
\hline 30 & 6 & 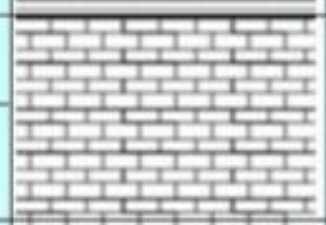 & $\begin{array}{l}\text { White to gray and high fractured } \\
\text { limestone. }\end{array}$ \\
\hline 50 & 8 & 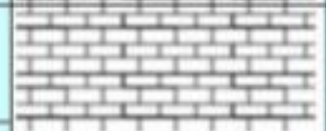 & Thinly bedded marl to shale. \\
\hline 20 & 9 & $\div \div-1=$ & \\
\hline 50 & 10 & 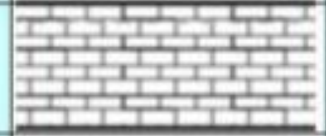 & White to gray limestone. \\
\hline 20 & 11 & 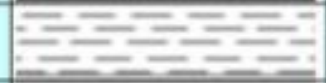 & $\begin{array}{l}\text { Finghy many limestone fo black } \\
\text { bituminous like shale. }\end{array}$ \\
\hline 50 & 12 & 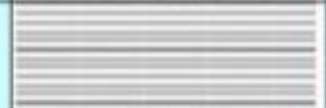 & Papery marly limestone. \\
\hline 50 & 13 & 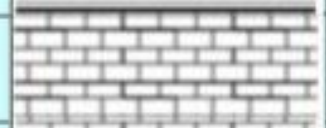 & White limestone. \\
\hline 50 & 14 & 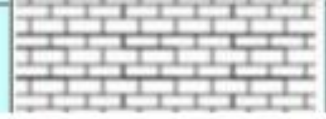 & $\begin{array}{l}\text { White to gray limestone to marly } \\
\text { limestone. }\end{array}$ \\
\hline \multicolumn{4}{|c|}{ Scale $=\mathrm{Iem}: 0.5 \mathrm{~m}$} \\
\hline & & Legened:- 藍 & Limestane \\
\hline & Fn $=$ Form & aation & Marl \\
\hline
\end{tabular}

Fig. 2: Stratigraphic Columnar Section of the Qulqula Formation. 

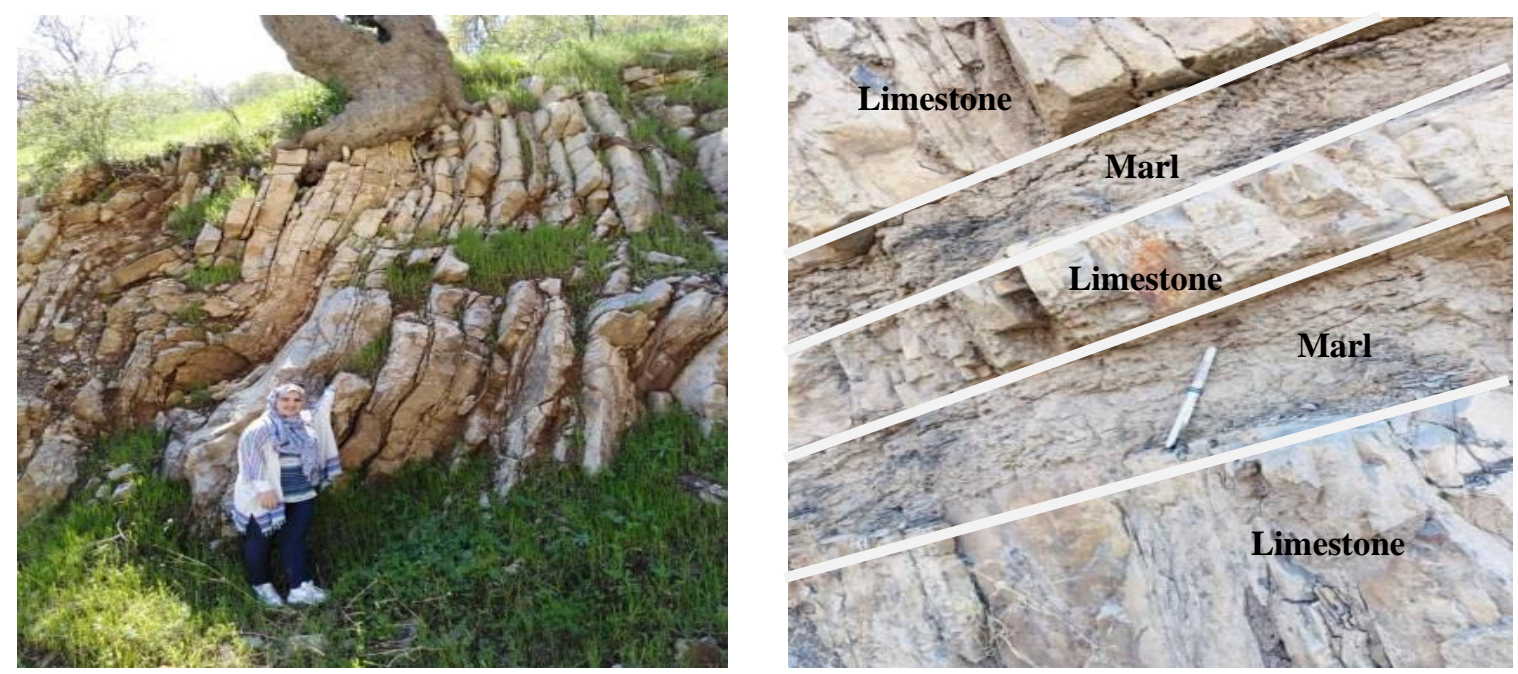

Fig. 3: Studied Section

\section{MATERIALS AND METHODS}

The fieldwork was carried out in Shenrui Mountain in the Halabja area, including the description of six selected sections from which twenty samples were collected from different beds of the Qulqula Limestone Formation. The laboratory work included preparing samples, crushing, sieving at 75 microns, and then analyzing their mineralogical composition using x-ray diffraction, type D2 phaser Bruker X-ray at Tamad Kala Laboratory in Iran. Several samples were scanned at $2 \Theta$ between $2-60^{\circ}$. The samples were also analyzed by x-ray fluorescence to determine their content of major oxides $\left(\mathrm{CaO}, \mathrm{MgO}, \mathrm{Fe}_{2} \mathrm{O}_{3}, \mathrm{MnO}, \mathrm{SiO}_{2}, \mathrm{Al}_{2} \mathrm{O}_{3}, \mathrm{Na}_{2} \mathrm{O}, \mathrm{K}_{2} \mathrm{O}, \mathrm{TiO}_{2}, \mathrm{SO}_{3}\right)$ and trace elements ( $\mathrm{Sr}, \mathrm{Cr}, \mathrm{Co}, \mathrm{Ni}, \mathrm{V}$, and $\mathrm{Zr}$ ). The loss on ignition (L.O.I) of the approximate carbon dioxide content of the same portion of the sample was determined by the weight loss on ignition at (1000-1100) $\mathrm{C}^{\mathrm{o}}$ for one hour.

\section{RESULTS AND DISCUSSION}

\section{Mineralogy}

The $\mathrm{x}$-ray diffraction analyses show that the main minerals of Qulqula limestone are calcite (d pacing: $3.04 \mathrm{~A}^{\circ}, 2.29 \mathrm{~A}^{\circ}, 2.1 \mathrm{~A}^{\circ}$ and $1.91 \mathrm{~A}^{\circ}$ respectively), calcite has a range of $66 \%-80 \%$ and an average of $70 \%$ (Table 2, Fig. 4). The second main mineral is quartz, which is identified at $\left(4.2 \mathrm{~A}^{\mathrm{o}}, 3.34 \mathrm{~A}^{\circ}\right.$, and $2.4 \mathrm{~A}^{\circ}$ respectively) and has a range between $17.33 \%-34 \%$, with an average of $28 \%$ (Table 2, Fig. 4). It is known that quartz is the most resistant mineral to chemical and mechanical weathering and the type of quartz was a guide to the nature of the source rocks (Al Ubaydi, 2008). The silica formation required a concentration of siliceous materials that were dispersed since the time of deposition. This might be the most probable source for silica in these rocks (Baban and Sarraj, 2007). 


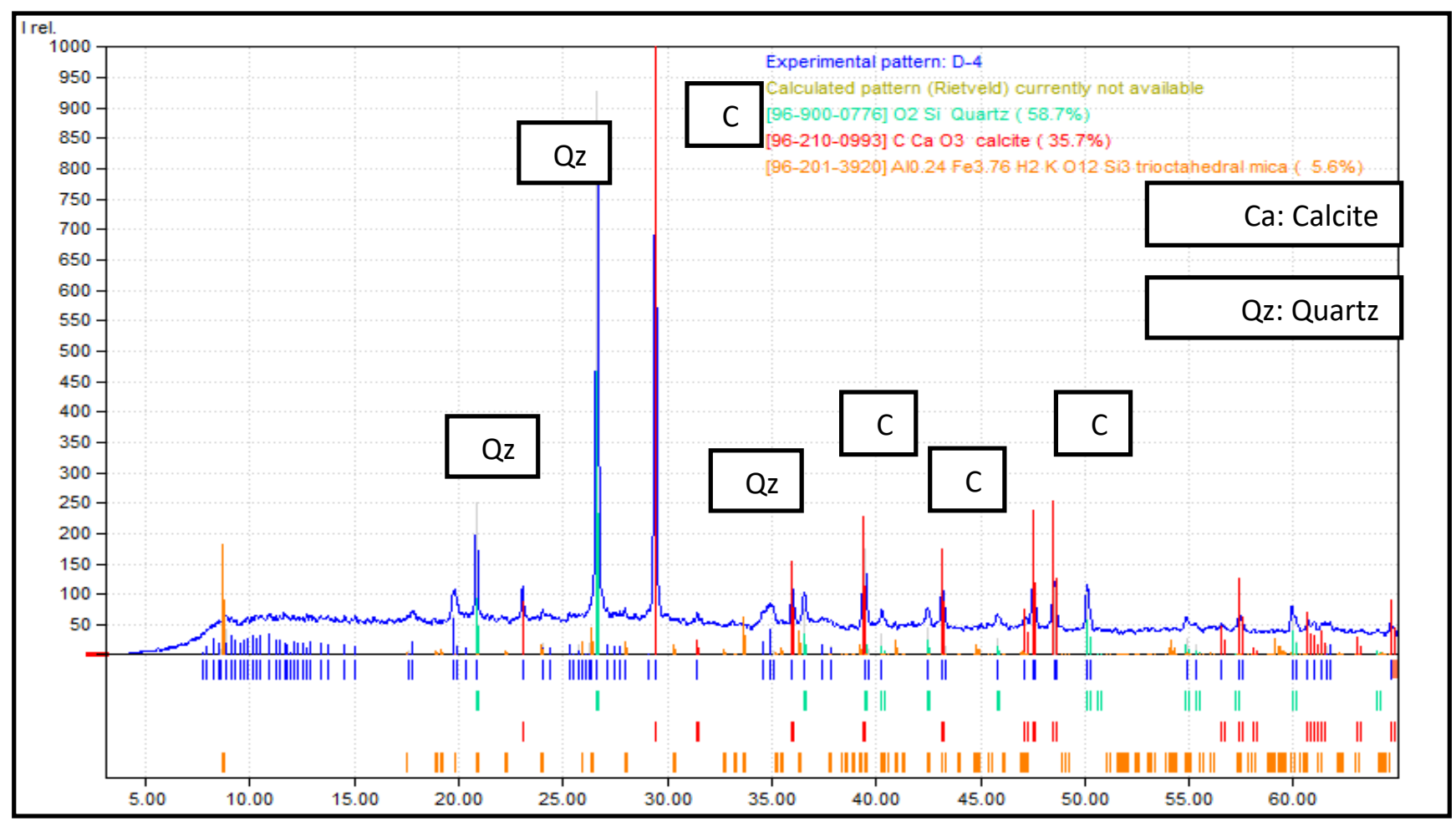

Fig. 4: X-ray diffractogram of Bulk Sample.

Table 2: The Relative Percentage of the Minerals in Selected Samples.

\begin{tabular}{|c|c|c|}
\hline sample & calcite & quartz \\
\hline A & $66 \%$ & $31 \%$ \\
\hline B & $70.8 \%$ & $28.6 \%$ \\
\hline C & $80.211 \%$ & $17.33 \%$ \\
\hline D & $66.465 \%$ & $32.3 \%$ \\
\hline E & $72.88 \%$ & $25.2 \%$ \\
\hline F & $64.475 \%$ & $34 \%$ \\
\hline Average & 70.14 & 28.07 \\
\hline
\end{tabular}

\section{GEOCHEMISTRY}

\section{Major Oxides:}

The objective of the analysis of the major elements is to understand the interelemental relationships, which would reflect the source rocks of the Qulqula Formation.

1. Calcium Oxide $(\mathrm{CaO})$ : The concentration of $(\mathrm{CaO})$ in the studied samples of the Qulqula Formation has a range between (27.95 and $51.22 \%$ ) with an average of $39.58 \%$ (Table 3 ). There is a wide variation in the concentrations of $\mathrm{CaO}$ in all studied sections, which is attributed to the alteration of limestone to marly limestone in some locations. $\mathrm{CaO}$ showed a negative relationship with $\mathrm{SiO}_{2}, \mathrm{Al}_{2} \mathrm{O}_{3}, \mathrm{Fe}_{2} \mathrm{O}_{3}, \mathrm{MgO}$, and $\mathrm{K}_{2} \mathrm{O}$. The negative relationship with $\mathrm{SiO}_{2}$ is attributed to the silicification, as well as with $\mathrm{Al}_{2} \mathrm{O}_{3}$. This revealed that clay minerals increase when carbonate constituents 
decrease due to dissolution. The clay minerals filled the cavities and pore spaces produced by dissolution processes. This might lead to the same conclusion for the strong negative relation of $\mathrm{CaO}$ with $\mathrm{TiO}_{2}$ and $\mathrm{K}_{2} \mathrm{O}$ (Al-Khafaji and Al-Saad, 2019) (Fig. 5).

2. Magnesium Oxide $(\mathrm{MgO})$ : The $(\mathrm{MgO})$ ranges between $(0.27$ and $1.33 \%)$ with an average of $0.59 \%$ (Table 3 ). Two sources represent the main supplier of magnesium in these rocks. $(\mathrm{MgO})$ in the carbonate, the fraction is present as a replacement for $\mathrm{Ca}$ in calcite (isomorphous substitution). On the other hand, the Mg content in the insoluble fraction could mainly be related to the clay minerals since it is one of the major constituents of this fraction (Raza, 2009). $\mathrm{MgO}$ shows a strong negative correlation with $\mathrm{CaO}$ (Fig. 5).

3. Iron Oxide $\left(\mathrm{Fe}_{2} \mathrm{O}_{3}\right)$ : The range of iron oxide is between $(0.65$ and $3.01 \%)$ with an average of $1.83 \%$ (Table 3). The general role for variation of $\left(\mathrm{Fe}_{2} \mathrm{O}_{3}\right)$ is the mobilization and fixation of iron during oxidation. The released iron is as oxides/hydroxides and $\mathrm{Mg}$ and $\mathrm{Al}, \mathrm{Ti}$, and $\mathrm{K}$ (Pendias, 1992) replace it. $\mathrm{Fe}_{2} \mathrm{O}_{3}$ showed a positive correlation with $\mathrm{Al}_{2} \mathrm{O}_{3}$ (Table 3).

4. Manganese Oxide $(\mathrm{MnO})$ : The range of $(\mathrm{MnO})$ content is between $(0.004$ and 0.008 $\%$ ) with an average of $0.006 \%$ (Table 3 ). There is a strong negative correlation of $\mathrm{MnO}$ with $\mathrm{CaO}$, and a strong positive correlation with $\mathrm{MgO}$ due to the substitution of $\mathrm{Ca}$ and $\mathrm{Mg}$ by $\mathrm{Mn}$ in carbonate minerals. $\mathrm{MnO}$ has a positive correlation with $\mathrm{Fe}_{2} \mathrm{O}_{3}$ because the manganese and iron are combined in an oxidizing condition (Falkum and Grundving, 2006).

5. Silica $\left(\mathrm{SiO}_{2}\right)$ : it ranges between (11.32 and 30.39\%) with an average of $20.86 \%$ (Table 3). According to X-ray analysis, the high $\mathrm{SiO}_{2}$ in some samples could be related to the terrigenous influx as well as the silicification process. Limestone shows that $\mathrm{SiO}_{2}$ concentrations are strongly negatively correlated with $\mathrm{CaO}$ due to a gradual decrease in quartz and subsequent enrichment of calcite. On the other hand, silica is positively correlated with $\mathrm{Al}_{2} \mathrm{O}_{3}$ and $\mathrm{Na}_{2} \mathrm{O}$ (Fig. 5), which are the main constituents of clay minerals and quartz (Velde, 2010). The presence of quartz is in a negligible quantity. There are two origins of $\mathrm{SiO}_{2}$ in the formation, according to some samples: clay minerals are the first source, and the siliceous skeleton is the second detritus source. The fact that $\mathrm{SiO}_{2}$ and $\mathrm{Al}_{2} \mathrm{O}_{3}$ have such a good positive association suggests they are the main components of clay. The high $\mathrm{SiO}_{2}$ levels in certain samples are likely related to silicification.

6. Alumina $\left(\mathrm{Al}_{2} \mathrm{O}_{3}\right)$ : Alumina has a range between $(0.32$ and $2.32 \%)$ with an average of $1.32 \%$ (Table 3). It shows a negative relationship with $\mathrm{CaO}$ (Fig. 5). The concentration is relatively low, which may be due to the presence of shale. The content of aluminum in carbonate rocks is mainly controlled by the amount of the non-carbonate constituents. The variation in $\left(\mathrm{Al}_{2} \mathrm{O}_{3}\right)$ contents is related to the variation in the insoluble residue contents. It is logical to state that all the $\left(\mathrm{Al}_{2} \mathrm{O}_{3}\right)$ content is related to clay minerals and the very few other insoluble silicate minerals (e.g. Al-Khafaji and Al-Saad, 2019). 

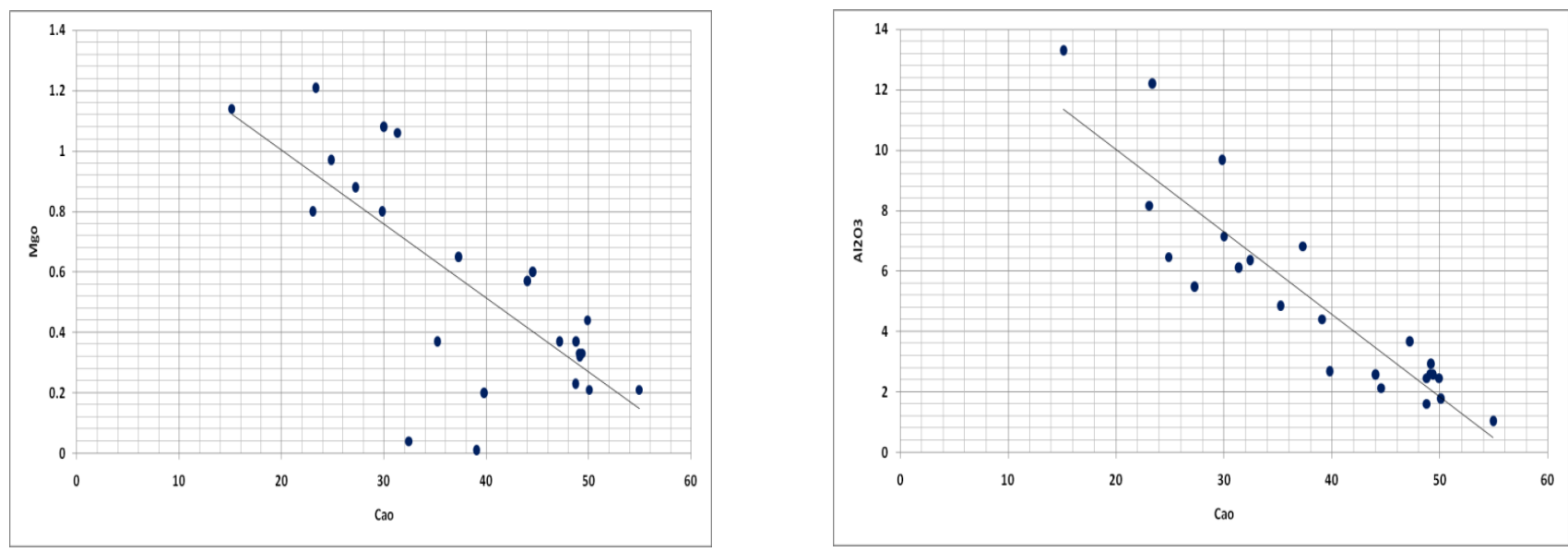

Fig. 5: The relationship diagrams $\mathrm{CaO}$ with, $\mathrm{MgO}$ and $\mathrm{Al} 2 \mathrm{O} 3$.

7. Sodium Oxide $(\mathrm{Na} 2 \mathrm{O})$ : The range of $(\mathrm{Na} 2 \mathrm{O})$ is between $(0.22 \%$ and $0.55 \%)$ with an average of $0.38 \%$ (Table 3 ). The strong positive correlations between $\mathrm{Na} 2 \mathrm{O}$, and $\mathrm{CaO}, \mathrm{SO} 3$ may be due to the high carbonate content, while the poor negative correlations with $\mathrm{K} 2 \mathrm{O}$ and $\mathrm{A} 12 \mathrm{O} 3$ are due to the clay minerals associated with carbonate in the rock.

8. Potassium Oxide (K2O): The range of $(\mathrm{K} 2 \mathrm{O})$ is between $(0.32 \%$ and $1.02 \%)$ with an average of $0.82 \%$ (Table 3$)$. The low content of (K2O) in carbonate rocks may be attributed to the low content of clay minerals associated with carbonate of Qulqula formation.

9. Titanium Oxide $(\mathrm{TiO} 2)$ : The range of $(\mathrm{TiO} 2)$ is between $(0.11 \%$ and $0.19 \%)$ with an average of $0.15 \%$ (Table 3 ). The concentration of ( $\mathrm{TiO} 2)$ in the samples is generally low. $\mathrm{TiO} 2$ shows a strong negative correlation with $\mathrm{CaO}$ and $\mathrm{TiO} 2$ with a strong negative association with $\mathrm{CaO}$, suggesting that these associations provide strong support for the limestone's terrigenous origin (Nagendra et al., 2011).

10. Sulfur Oxide $\left(\mathrm{SO}_{3}\right)$ : The range of $\left(\mathrm{SO}_{3}\right)$ is between $(0.02$ and $0.63 \%)$ with an average of $0.315 \%$ (Table 3$)$. The low concentration of $\left(\mathrm{SO}_{3}\right)$ in all samples indicates that sulfur content in carbonate rocks has no phase mineral (Al-Khafaji and Al-Saad, 2019).

11. L.O.I.: The loss on ignition has a range between (22\% and $33 \%)$ with an average of $27.5 \%$ (Table 3 ). Since the samples contain $70 \%$ calcite, the burning loss is mostly carbon dioxide, and crystallization water does not account for a large portion due to the low concentration of clay minerals. The abundance of organic matter, as well as the carbonate component of the sediment, led to a rise in the percentage of loss on ignition (LO.I), which is largely due to carbon dioxide $\left(\mathrm{CO}_{2}\right)$ produced from the carbonate fraction of the sediment. (Raza, 2009). 
Table 3: Chemical analysis of major oxides (wt \%) of Qulqula Formation (20 samples).

\begin{tabular}{|c|c|c|c|c|c|c|c|c|c|c|c|c|}
\hline $\begin{array}{c}\text { Sample } \\
\text { no. }\end{array}$ & $\mathrm{CaO}$ & $\mathrm{MgO}$ & $\mathrm{Na}_{2} \mathrm{O}$ & $\mathrm{K}_{2} \mathrm{O}$ & $\mathrm{Mno}$ & $\mathrm{TiO}_{2}$ & $\mathrm{Al}_{2} \mathrm{O}_{3}$ & $\mathrm{SiO}_{2}$ & $\mathrm{Fe}_{2} \mathrm{O}_{3}$ & $\mathrm{SO}_{3}$ & L.O.I & TOT \\
\hline $\mathrm{A} 1$ & 46.99 & 0.28 & 0.32 & 0.55 & 0.005 & 0.17 & 1.02 & 22.32 & 0.76 & 0.02 & 32 & 104.4 \\
\hline $\mathrm{A} 2$ & 44.31 & 0.33 & 0.34 & 0.44 & 0.006 & 0.16 & 1.33 & 25.44 & 1.24 & 0.05 & 28 & 101.6 \\
\hline $\mathrm{A} 3$ & 39.77 & 0.27 & 0.22 & 0.73 & 0.004 & 0.19 & 1.22 & 28.34 & 1.45 & 0.21 & 28 & 100.4 \\
\hline $\mathrm{B}$. & 44.78 & 0.36 & 0.22 & 1.02 & 0.008 & 0.19 & 0.32 & 30.39 & 2.04 & 0.19 & 30 & 109.5 \\
\hline $\mathrm{B} 1$ & 42.64 & 1.03 & 0.31 & 0.73 & 0.004 & 0.17 & 0.39 & 28.33 & 1.76 & 0.32 & 31 & 104.6 \\
\hline $\mathrm{B} 2$ & 44.67 & 1.22 & 0.44 & 0.54 & 0.008 & 0.14 & 0.34 & 29.33 & 1.54 & 0.27 & 33 & 111.4 \\
\hline $\mathrm{B} 3$ & 50.11 & 1.33 & 0.42 & 0.54 & 0.006 & 0.15 & 0.4 & 30.11 & 1.08 & 0.44 & 30 & 114.4 \\
\hline $\mathrm{C} 1$ & 28.45 & 0.45 & 0.28 & 1.05 & 0.008 & 0.17 & 0.44 & 32 & 0.88 & 0.23 & 27 & 90.9 \\
\hline $\mathrm{C} 2$. & 44.87 & 0.27 & 0.55 & 1.02 & 0.007 & 0.16 & 0.32 & 17.44 & 1.32 & 0.63 & 29 & 95.5 \\
\hline $\mathrm{C} 3$ & 47.33 & 0.62 & 0.48 & 1.02 & 0.004 & 0.17 & 0.54 & 18.44 & 1.32 & 0.55 & 28 & 98.4 \\
\hline $\mathrm{C} 4$ & 32.9 & 0.27 & 0.41 & 0.88 & 0.008 & 0.19 & 0.44 & 33.4 & 1.04 & 0.45 & 30 & 99.9 \\
\hline D. & 47.44 & 0.32 & 0.49 & 0.87 & 0.004 & 0.17 & 1.39 & 20.22 & 1.77 & 0.04 & 33 & 105.7 \\
\hline D2 & 51.22 & 0.34 & 0.41 & 1.04 & 0.006 & 0.18 & 1.66 & 18.55 & 2.11 & 0.02 & 32 & 107.5 \\
\hline D3 & 33.04 & 1.03 & 0.38 & 0.22 & 0.004 & 0.14 & 1.54 & 22.6 & 2.62 & 0.04 & 28 & 89.6 \\
\hline E. & 44.56 & 0.51 & 0.27 & 0.34 & 0.008 & 0.19 & 2.32 & 11.32 & 3.01 & 0.08 & 32 & 94.6 \\
\hline E1 & 45.4 & 1.22 & 0.22 & 0.55 & 0.004 & 0.17 & 1.66 & 30.33 & 2.44 & 0.03 & 28 & 110 \\
\hline E2 & 42.43 & 0.33 & 0.22 & 0.32 & 0.004 & 0.12 & 1.54 & 28.89 & 2.64 & 0.11 & 30 & 106.6 \\
\hline F1 & 38.7 & 0.46 & 0.34 & 0.32 & 0.008 & 0.11 & 1.22 & 28.45 & 0.67 & 0.23 & 24 & 94.5 \\
\hline F2 & 27.95 & 0.42 & 0.32 & 0.41 & 0.007 & 0.12 & 0.88 & 28.44 & 0.68 & 0.44 & 28 & 87.6 \\
\hline F.3 & 46.33 & 0.3 & 0.3 & 0.32 & 0.008 & 0.11 & 1.05 & 20.56 & 0.65 & 0.06 & 22 & 91.6 \\
\hline MAX & 51.22 & 1.33 & 0.55 & 1.05 & 0.008 & 0.19 & 2.32 & 33.4 & 3.01 & 0.63 & 33 & 126.7 \\
\hline MIN & 27.95 & 0.27 & 0.22 & 0.22 & 0.004 & 0.11 & 0.32 & 11.32 & 0.65 & 0.02 & 22 & 63 \\
\hline MAEN & 39.58 & 0.58 & 0.38 & 0.64 & 0.006 & 0.15 & 1.03 & 20.58 & 1.83 & 0.315 & 27.5 & 92.5 \\
\hline
\end{tabular}

\section{Trace elements:}

Trace elements are considered as indicators to determine the depositional environment and origin of carbonate rocks. The results of trace element analysis in the studied samples are listed in Table (4).

1. Strontium is available in the studied samples. It ranges between 300 and 1000 ppm with an average of $650 \mathrm{ppm}$. A comparison between the strontium content of limestones, with some other published data, is shown in Table (5). It shows a positive correlation with $\mathrm{CaO}$. The limited dolomitization can be confirmed by the low concentration of $\mathrm{Sr}$ element and a negative correlation with other oxides (Wilson, 1989) (Fig. 6).

2. Chromium concentrations range between $<1$ to $200 \mathrm{ppm}$ with an average of $40 \mathrm{ppm}$ (Table (4). The strong positive correlation between $\mathrm{Cr}$ with $\mathrm{CaO}, \mathrm{MgO}, \mathrm{Fe}_{2} \mathrm{O}_{3}$, $\mathrm{Al}_{2} \mathrm{O}_{3}, \mathrm{TiO}_{2}, \mathrm{Co}$, and $\mathrm{Ni}$ (Fig. 7) displays that it is related to the clay minerals in the rock.

3. Cobalt concentrations range between $<3$ and $<30 \mathrm{ppm}$ with an average of $5 \mathrm{ppm}$ (Table 4). The mean cobalt in the five studied sections is similar to the average contents given by different workers (Table 5). This element has very few concentrations in the studied samples and no positive relationship has been observed with trace elements and oxides. 
4. Nickel concentrations range between (10 and $190 \mathrm{ppm})$ (Table 4). It is usually found in the clay minerals as adsorption on the clay grain surface. Nickel exhibits opposite cobalt behavior in the studied samples where the relationship is a positive correlation (Fig. 6). Table 5) shows a comparison between the Ni content in all studied sections of limestone and other carbonate rocks of other published data.

5. Vanadium ranges between 80 and $880 \mathrm{ppm}$ with an average of $440 \mathrm{ppm}$ (Table 4), and through the positive relationship with the oxides $\left(\mathrm{CaO}, \mathrm{MgO}, \mathrm{Fe}_{2} \mathrm{O}_{3}, \mathrm{MnO}\right.$, $\mathrm{SiO}_{2}, \mathrm{Al}_{2} \mathrm{O}_{3}, \mathrm{Na}_{2} \mathrm{O}, \mathrm{K}_{2} \mathrm{O}, \mathrm{TiO}_{2}, \mathrm{SO}_{3}$, it is possible to reveal the origin of the rocks (Pendias, 2011) that vanadium found in the crystal unit of clay minerals as a substitution for Al.

6. Zirconium in the studied samples shows a range between $<3$ and 100ppm with an average of $45 \mathrm{ppm}$ (Table 4). Zirconium is almost found as zircon that is a resistant mineral transported from the source rocks. Zirconium in carbonate rocks of the studied formations shows a positive correlation with $\mathrm{SiO}_{2}, \mathrm{Al}_{2} \mathrm{O}_{3}$ (Fig. 8). The existence of zirconium in high values of some samples indicates the secondary acidic igneous rocks of carbonate rocks (Majid, 2015).
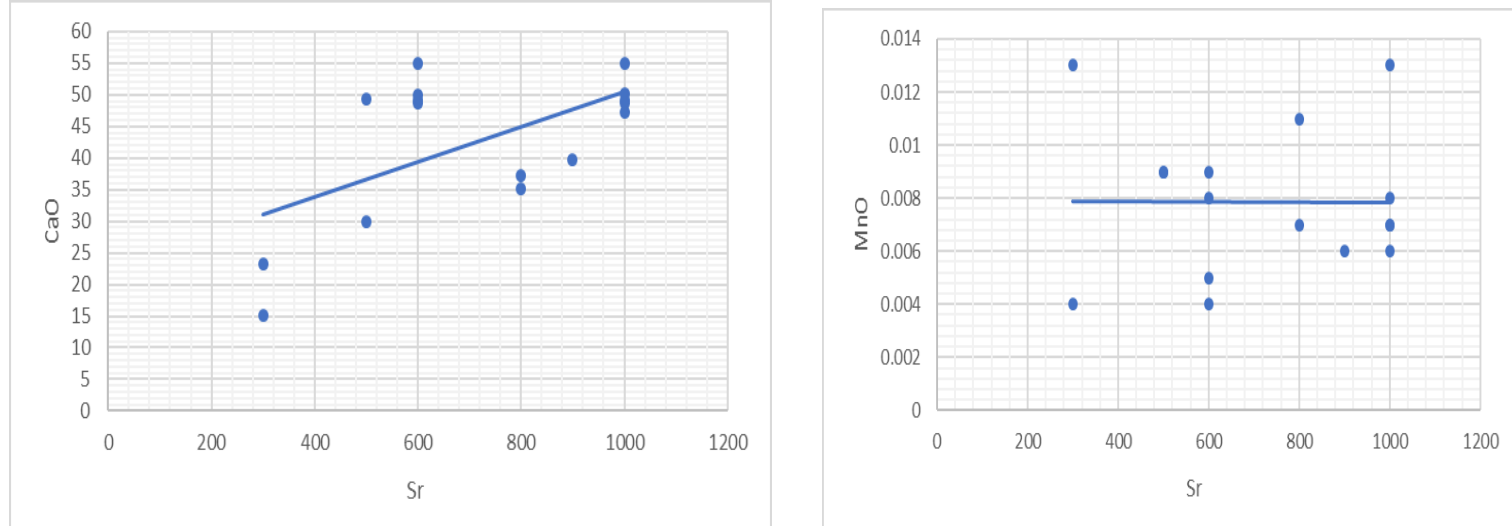

Fig. 6: The relationship Diagrams of $\mathrm{Sr}$ with $\mathrm{CaO}, \mathrm{MnO}$.
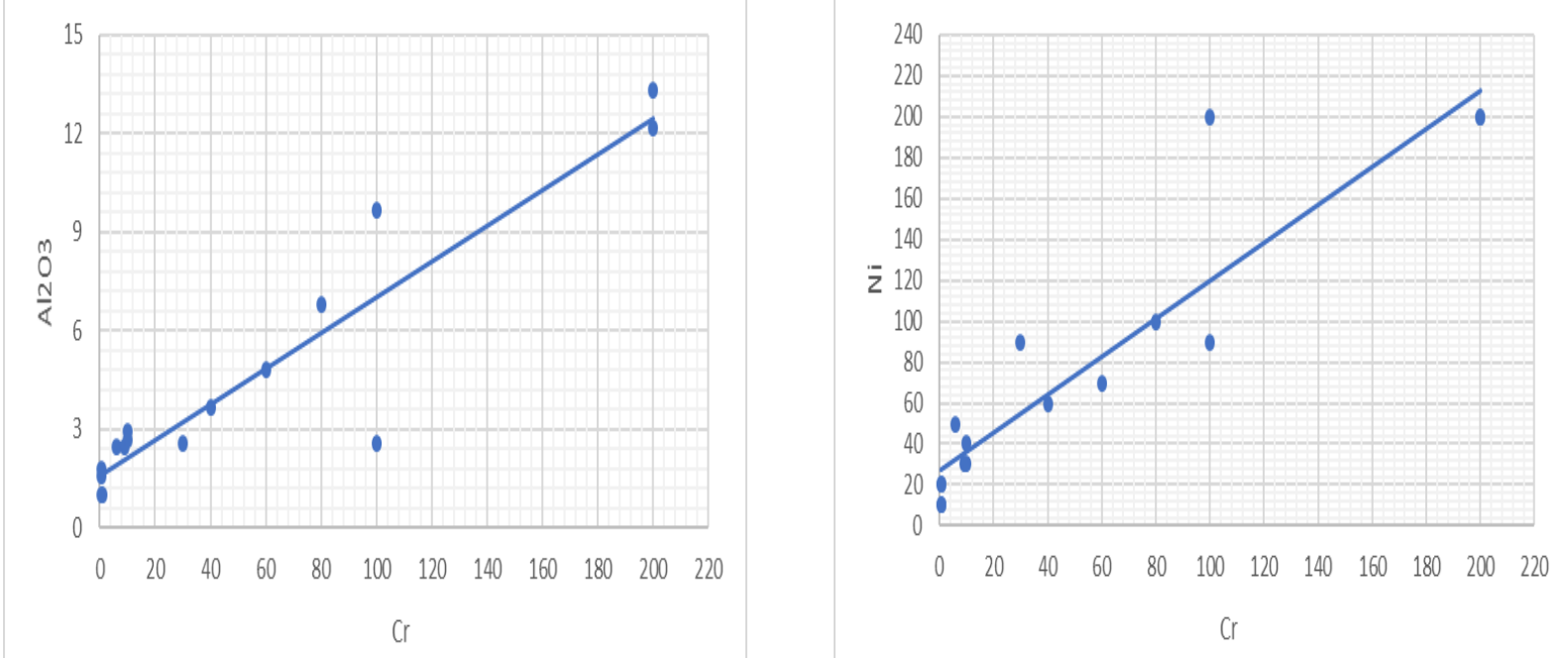

Fig. 7: The relationship diagrams of $\mathrm{Cr}$ with $\mathrm{Al}_{2} \mathrm{O}_{3}$, and $\mathrm{Ni}$. 
11 Mineralogy and Geochemistry of limestone of Qulqula formation ......

Table 4: Chemical Analysis of Trace Elements (ppm) of (20 samples) of the Qulqula Formation.

\begin{tabular}{|c|c|c|c|c|c|c|}
\hline Sample no. & Sr & Cr & Co & Ni & V & Z \\
\hline A1 & 500 & $<3$ & $<3$ & 40 & 150 & 30 \\
\hline A2 & 700 & 30 & $<3$ & 10 & 800 & $<3$ \\
\hline A3 & 1000 & $<1$ & $<3$ & 20 & 650 & 50 \\
\hline B. & 600 & $<6$ & $<7$ & 90 & 400 & 70 \\
\hline B1 & 300 & 100 & $<3$ & 190 & 300 & 60 \\
\hline B2 & 600 & 60 & $<10$ & 70 & 200 & 30 \\
\hline B3 & 500 & 80 & $<3$ & 90 & 100 & $<3$ \\
\hline C1 & 700 & $<7$ & $<6$ & 80 & 200 & 70 \\
\hline C2. & 500 & 80 & $<3$ & 40 & 400 & 40 \\
\hline C3 & 700 & 40 & $<10$ & 40 & 600 & 100 \\
\hline C4 & 1000 & 60 & $<3$ & 30 & 80 & 60 \\
\hline D. & 600 & 10 & $<3$ & 60 & 190 & 40 \\
\hline D2 & 900 & 40 & $<30$ & 10 & 80 & 20 \\
\hline D3 & 500 & 30 & $<3$ & 40 & 700 & 20 \\
\hline E. & 600 & 10 & $<3$ & 70 & 400 & 60 \\
\hline E1 & 600 & 40 & $<30$ & 20 & 500 & 20 \\
\hline E2 & 300 & 200 & $<3$ & 190 & 300 & 60 \\
\hline F1 & 700 & $<6$ & $<3$ & 60 & 260 & 40 \\
\hline F2 & 1000 & $<1$ & $<3$ & 20 & 80 & 20 \\
\hline F3 & 500 & 60 & $<3$ & 30 & 100 & 80 \\
\hline Min. & 300 & $<1$ & $<3$ & 10 & 80 & $<3$ \\
\hline Max. & 1000 & 200 & $<30$ & 190 & 800 & 100 \\
\hline Mean. & 650 & 40 & $<5$ & 65 & 440 & 45 \\
\hline & & & & & & \\
\hline
\end{tabular}
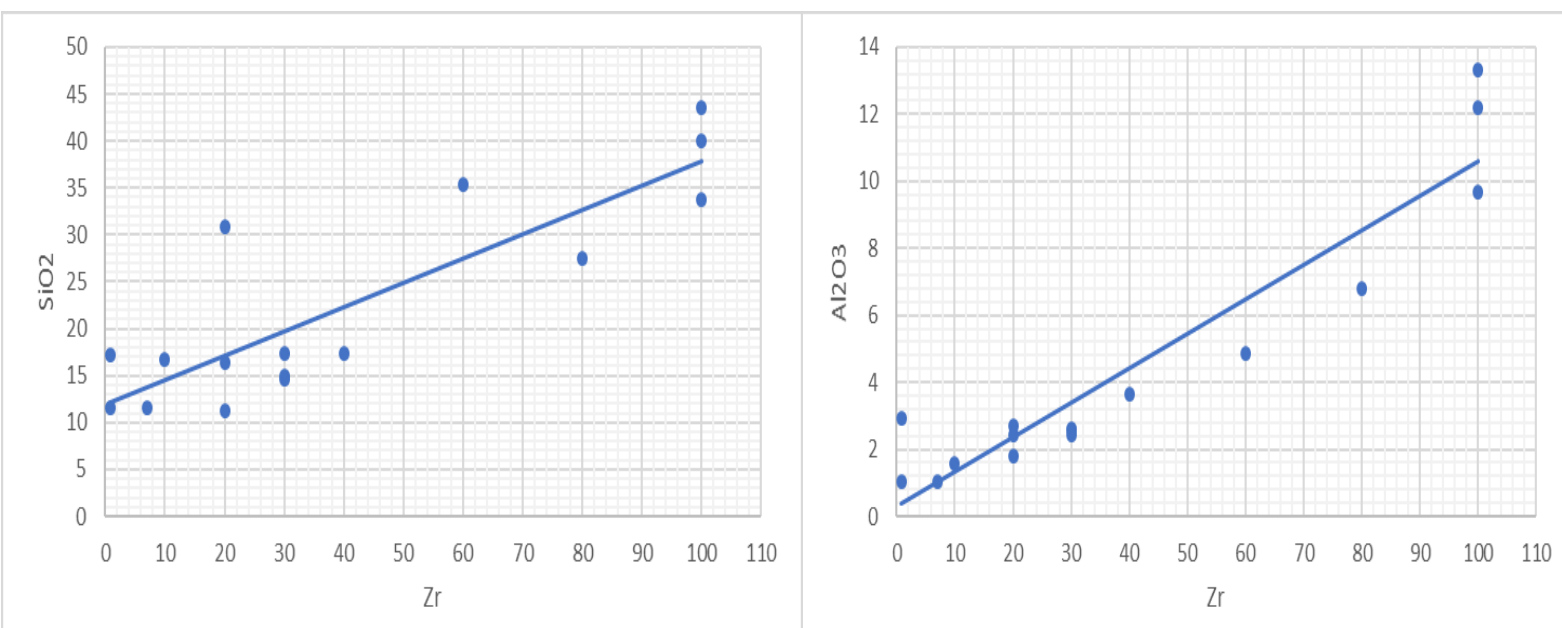

Fig. 8: The relationship diagrams of $\mathrm{Zr}$ with $\mathrm{SiO}_{2}, \mathrm{Al}_{2} \mathrm{O}_{3}$. 
Table 5: shows a comparison between the $\mathrm{Ni}, \mathrm{Co}$, and $\mathrm{Sr}$ content of limestone beds of the studied sections, with some other published data.

\begin{tabular}{|l|c|c|c|c|}
\hline \multirow{2}{*}{ Standard } & Type of rock or sed. & $\mathrm{Ni}$ & $\mathrm{Co}$ & $\mathrm{Sr}$ \\
\cline { 2 - 5 } & Argill Lst & 60 & 25 & 250 \\
\hline Sarkan & Black Lst & 22.14 & 22.71 & 360 \\
\hline Awera & Black Lst & 30.11 & 21.56 & 552 \\
\hline Grian2 & Black Lst & 28.33 & 30.11 & 610 \\
\hline Hawa & Black Lst & 22,14 & 33.45 & 440 \\
\hline Rankama and Sahama,1950 & Carbonate rocks & & & 490 \\
\hline Ostrom,1957 & limestone & 17 & & 595 \\
\hline Al-Hashimi, 1972 & limestone & & & 618 \\
\hline Al-Jawadi, 1978 & PilaSpi Limestone & & & 341 \\
\hline Younis, 1979 & Miocene Carbonate & 13.58 & & 868 \\
\hline Al-Haza'a,1996 & Limestone Zahra Fm. & 91 & 84 & 275 \\
\hline
\end{tabular}

\section{CONCLUSIONS}

1- The dominant minerals of the studied sections are calcite with an average concentration of $70.137 \%$ and quarts $28.071 \%$.

2- The chemical result of the major oxides shows a high concentration in $\mathrm{CaO}$ and a relatively high concentration of LOI that reflects the existence of limestone commonly in the overall studied samples.

3- The low content of $\left(\mathrm{Na}_{2} \mathrm{O}\right)$ in studied samples indicates recrystallization of the expected limestone.

4- The concentration of alumina $\mathrm{Al}_{2} \mathrm{O}_{3}$ is relatively high which may refer to the presence of clay minerals.

5- The low concentration of $\left(\mathrm{SO}_{3}\right)$ indicates that sulfur content has no phase mineral, so there is no effect on forming new minerals other than expecting new rocks.

6- The limitation of dolomitization can be confirmed by the low concentration of $\mathrm{Sr}$ element.

7- The high alteration of limestone to marly limestone and marl, and then to marl like shale, was discovered by the strong negative association between $\mathrm{CaO}$ and other oxides $\mathrm{MgO}, \mathrm{Fe}_{2} \mathrm{O}_{3}, \mathrm{MnO}, \mathrm{SiO}_{2}, \mathrm{Al}_{2} \mathrm{O}_{3}, \mathrm{~K}_{2} \mathrm{O}$, and $\mathrm{TiO}_{2}$.

\section{ACKNOWLEDGMENTS}

I would like to gratefully acknowledge the help and support of, Prof. Dr. Sattar J. Al-Khafaji; for reviewing the research and for providing me with his valuable remarks.

\section{REFERENCES}

Al-Hashimi, W. S., (1976). Significance of Strontium distribution in some Carbonate rocks in the Carboniferous of North-Umber land, England, Journal of Sedimentology and petrology, Vol.46, No.2, PP (369-376). 
Al-Haza'a, S. F., (1996). Sediment logical and geochemical studies of Zahra Formation (Pliocene-Pleistocene) in the western and southern desert of Iraq, University of Baghdad. 108P.

Al-Jawadi, A. F., (1978). Mineralogical, Petro graphical, and Geochemical studies on Pila Spi formation from Northern Iraq, Unpublished MSc thesis, University of Mosul, 157P.

Al-Kawaz, A. and Aljubouri, A., (2006). Mineralogy and Petrography of Marl Sediments within the Fat ha Formation in Selected Parts of Northern Iraq, Raf. Jour. Sci., Vol.17, No.1, pp.19- 31

Al-Khafaji, J. and Al-Saad, A. and Luaibi, S., (2019). Mineralogy, Petrography, And Geochemistry, Of Gulneri Formation (Cenomanian-Turonian) in Sulaimania area, NE-Iraq. M.Sc. thesis, University of Basrah, 145P.

Al-Ubaydi, M. M., (2008). Heavy mineral study of the Red Bed Series and stream sediments from the western part of Mawat-Chwarta area, NE Iraq. University of Baghdad, $125 \mathrm{p}$.

Baban, H., and Sarraj, H., (2007). Palynofacies analysis and hydrocarbon generation potential of Dokan and Gulneri Formations (Upper Cretaceous) from selected wells in Northern Iraqi Oil Fields Journal of Kirkuk University, vol.2, No.3,17-34.

Baziany, M. Q., (2006). Sedimentology and stratigraphy of Qulqula Conglomerate Formation, Kurdistan region, NE-Iraq. Unpublished M. Sc. thesis, University of Sulaiman, 103.

Bolton, C. G., (1955). B. Report on the geology and economic prospect of the Qala Dizeh area Site Inv. Co. Report, SOM Library. No. 269, Baghdad.

Buday, T. C., (1980). Regional Geology of Iraq: Vol. 1, Stratigraphy, I.I.M Kassab and S. Z. Jassim (Eds) D. G. Geol. Surv. Min. Invest. Publ. 445p.

Buday, T., and Jassim, S.Z., (1987). Regional geology of Iraq: Tectonism magmatism, and metamorphism. I.I.Kassab and M.J. Abbas (Eds). Baghdad: Iraqi Geological Survey and Mineral Investigation Press.

Dunnington, H. V., (1958). Generation, Migration, and Dissipation of Oil in northern Iraq. Arabian Gulf, Geology and Productivity. AAPG, Foreign Reprint Series No. 2.

Falkum, T., and Grundving, S., (2006). Geochemical evidence in support of sedimentary precursors to proterozoic sillimanite-bearing rocks, Vest- Agder, South Norway Norges geologist under sikelse Bulletin 446, pp.19-34.

Gill, J. B., (1981). Orogenic Andesites and Plate Tectonics. Springer, Berlin.

Jassim, S. Z., Karim, S. A., Basi, M. A., Al-Mubarak, M. A. and Munir, J., (1984). Final report on the regional geological survey of Iraq. Vol.3, Stratigraphy, Geosurv, Baghdad, Lib, No.1447. 498p. 
Jassim, S.Z. and Goff, J.C., (2006). Geology of Iraq, Published by Dolin, Prague and Moravian Museum, Brno, Czech Republic, 341P.

Karim, S. A., (1975). Biostratigraphy of the Red Bed Series, Chuarta, NE Iraq. Jour. Geol. Soc. Iraq, special issue, pp.147-156.

Karim, K. H., (2003). A conglomerate bed as a possible lower boundary of Qulqula Formation, from Chuarta-Said Sadiq area, NE Iraq. Kurdistan Academician Journal (KAJ), Vol.2.Part A.

Lawa, F.A., Koyi, H., and Ibrahim, A., (2013). Tectono-stratigraphic evolution of the NW segment of the Zagros fold-thrust Belt, Kurdistan, NE Iraq. Journal of Petroleum Geology 36 (1): 75-96.

Majid A. K. and Habib R. H., (2015). Mineralogy Of Palygorskite-Rich Claystone in Gercusformation, Dohuk Governorate, Northern Iraq, Journal of Iraqi Bulletin of Geology and Mining Vol.11, No.2, p 75 - 91

Nagendra, R., Nagarajan, R., Bakkiaraj, D., and Armstrong-Aldrin, J. S., (2011). The depositional and post-depositional setting of Maastrichtian limestone, Ariyalur Group, Cauvery Basin, South India: a geochemical appraisal. Carbonates Evaporites 26: 127-147.

Pendias, H., (1992). Trace elements in soil and plants. $2^{\text {nd }}$ ed., CRC. Press. Boca Raton. FL.

Pendias, K. A., (2011). Trace Elements in Soil and Plants.4th ed. Tylor and Frances Group. 450 P.

Rankhama, K., and Shahama, Th. G., (1950). Geochemistry. The Book University of Chicago. Press. 912 P.

Raza, S. M., (2009). Sedimentology and Geochemistry of The Limestone Successions of The Lower Member of the Qulqula Formation Kurdistan region, NE-IRAQ, University of Sulaimania, 161P. The region, NE-Iraq. Geological Magazine, Cambridge University Press, 148(5-6): 925-939.

Sissakian, V. K., (2005). The stratigraphy of the exposed Cretaceous rocks in Iraq, as deduced from the result of the regional detail geological survey (Geoserve 19711996). Iraqi Bulletin of geology and mining. Baghdad. Vol. 1, No.1 pp.1-20.

Stocklin, J., (1968). Structural history and tectonics of Iran: a review. American Association of Petroleum Geologists Bulletin 52, pp.1229-1258.

Veldo, B. and Barre, P., (2010). Soil, Plants and Clay minerals. Minerals and biologic interaction. Springer, verlag berlin Hoidelberg.

Wilson, R. B., and Govaindraju, (1994). Trace element and Sr-Nd isotopic geochemistry of the PGE-bearing Xinjie layered intrusion in SW Chemical Geology, 237-252.

Younis, M. T., (1979). Geochemical and Mineralogical studies with Petrographical description of the Miocene Carbonate Rocks in the Eastern part of Jabal Alan, Northern Iraq, Unpublished MSc thesis, University of Mosul. 